\title{
Transformational Leadership and Turnover Intentions: The Mediating Role of Employee Performance during the COVID-19 Pandemic
}

\author{
İlhami Yücel (1)
}

Citation: Yücel, İlhami. 2021. Transformational Leadership and Turnover Intentions: The Mediating Role of Employee Performance during the COVID-19 Pandemic. Administrative Sciences 11: 81. https://doi.org/10.3390/ admsci11030081

Received: 4 July 2021

Accepted: 19 July 2021

Published: 11 August 2021

Publisher's Note: MDPI stays neutral with regard to jurisdictional claims in published maps and institutional affiliations.

Copyright: (C) 2021 by the author. Licensee MDPI, Basel, Switzerland. This article is an open access article distributed under the terms and conditions of the Creative Commons Attribution (CC BY) license (https:/ / creativecommons.org/licenses/by/ $4.0 /)$.
Business Administration Department, Erzincan Binali Yıldırım University, 24100 Erzincan, Turkey; iyucel@erzincan.edu.tr

\begin{abstract}
The purpose of this research paper is to explain the impact of transformational leadership on employees' turnover intentions in light of the mediating role of their individual performance. More precisely, we attempt to explain (a) how TL connects to employees' turnover intentions, (b) how TL connects to employee performance, (c) how employee performance connects to turnover intentions, and (d) how employee performance mediates the connection between intentions and TL. Four hundred and seventy-eight Turkish healthcare professionals participated in this research. The results revealed that employee performance mediates the connection between turnover intentions and TL. In other words, transformational leaders encourage employee performance, which in turn decreases their turnover intentions. This research has important implications for reducing turnover in workplaces and increasing employee performance by facilitating a setting for high performance, since employees who are supported by their leaders are generally more committed to their organizations and exhibit better performance. This research answers calls to study the mediating function of the TL procedure, since the mediation clarifies the circumstances under which TL relates to the favorable results.
\end{abstract}

Keywords: transformational leadership; employee performance; turnover intention

\section{Introduction}

Leadership plays an important role in growing organizations and in individual performance. For stockholders to get the most out of their investments, they should produce the best services and goods possible from the optimum resources of an enterprise, by improving and implementing organizational strategic decisions. A leader must provide his/her followers with what they need to be effective and to move towards a common vision. Moreover, employees will be demotivated and lose confidence if their leaders refuse to provide what they have promised. In order to improve employee performance, leaders need to concentrate on the employees' external and internal needs. Leaders develop a vision, and then they adapt organizational and individual goals to achieve their individual and organizational priorities by sharing this perspective and by empowering their employees to overcome challenges (Robbins 2003). A competent leader gives the group guidance and leads followers to the right objectives.

Cases of pneumonia of an unspecified cause were recorded by the World Health Organization (WHO) in Wuhan, China, on 31 December 2019. On 7 January 2020, the Chinese authorities found a new coronavirus, which was reportedly called "2019-nCoV". Coronaviruses $(\mathrm{CoV})$ include a broad range of viruses that cause diseases from colds to more extreme conditions. Again, the new strain, which was not previously detected in humans, represents a novel coronavirus $(\mathrm{nCoV})$. The new virus was later called the "COVID-19 virus" (World Health Organisation 2020). Almost every country in the world, including Turkey, has been affected by the coronavirus. The first COVID-19 case was detected in Turkey on 10 March 2020, and the first death occurred on 17 March 2020 (T.C. 
Sağlık Bakanlığı 2020b). Its fast spread was incredibly concerning (T.C. Sağlık Bakanlığı 2020a). Based on statistics from the World Health Organization (WHO), about 215 nations, such as Turkey, have been affected by this pandemic. When considering day-to-day statistical data on the number of incidents, the spread of COVID-19 in Turkey is still developing (T.C. Sağlık Bakanlığı 2020b).

During this pandemic, hospital employees did not take holidays, and it was not possible for them to resign or retire. Discipline requires consciousness. The path to success requires discipline. Work should be conducted in accordance with defined goals. This virus causes casualties daily, so the government has urged citizens to remain secure at home in order to preserve physical distancing and social isolation, and even performed regional quarantining to stop the transmission of the coronavirus. The WHO states that a sore throat, unexplained pain, aches, shortness of breath, a dry cough, tiredness, and fever are the main signs of COVID-19 infection. The COVID-19 response has had significant effects on people's lives and restricted their travel. In Turkey, as in most nations around the world, it was said that in order to prevent or minimize the spread of the virus, people should not travel unless they need to. Moreover, citizens could not visit or move to quarantined municipalities except under compulsory circumstances. These steps demonstrate the seriousness of the condition and the mobility of the virus (T.C. Sağlık Bakanlı̆̆1 2020a, 2020b; World Health Organisation 2020).

Concrete reactive and proactive action was taken on the national, organizational, and individual levels to effectively handle the COVID-19 pandemic. Government policies attempted to limit the effects of the lockdowns on employment by protecting existing jobs and providing productive work for those who became unemployed. The nation focused on community actions such as social distancing, which reduced COVID-19's spread, allowing healthcare services to brace for and deal with the patient influx. By shutting their borders, many nations attempted to limit spread in their own countries. Likewise, they acted rapidly to limit commercial trade to isolate their populations. The introduction of larger-scale IT systems for many companies, along with the shift to working from home, were flexible steps undertaken to address the problems of the COVID-19 crisis immediately. These developments have also caused stress, anxiety, panic, other negative emotions, and sudden shocks that have had progressive consequences. The confidence of organizations and the commitment levels their workers have been reduced as well.

Several experiments were documented in the literature over the last year in which researchers developed general management practices which exemplary leaders apply in normal times, and they emphasized that five main practices have significant benefits when leading an organization toward specific goals (Ribeiro et al. 2018a).

In the current era of uncertainty, employee productivity is low, unemployment is high, and workers are faced with many new challenges. Crisis management requires a strong connection between managers and employees. Such connections always have significant effects upon organizations' performances. A leader should have foresight, discipline, objectivity, positive accountability, knowledge of the world, and sound argumentative abilities. In the first place, a leader should acknowledge and respect the characteristics of his subordinates, which should lead to greater organic allegiance and engagement. At the same time, a leader has to be agile, and prioritize requirements rather than react to momentum. He/she must transfer information rapidly to all levels with decisive adaptability. In order to support the mental, emotional, and physical wellbeing of employees, certain actions of all leaders need to be weighed and streamlined, and organizations are expected to prioritize cooperation instead of confrontation from an operational perspective. Employees are more likely to respond well to complex, difficult experiences with twodimensional (interpersonal and emotional) assistance. They require respect, strengthening, and enjoyment of work to adjust to the current work reality. Leadership is understood to be a mechanism in which someone else influences a purpose through nature and ability, and leads the organization in a manner that makes it more unified and coherent. Leaders' skills and knowledge are closely connected to their traits or attributes, for example, ethics, beliefs, 
values, and character. When leadership is taught, skills and knowledge contribute directly to development of a pragmatic and harmonious vision linked to the art of communication in the leadership phase, whilst the other characteristics give the leader several virtues and characteristics that give him/her singularity.

Leading a company in a serious medical situation is a stressful action when the leader's position and power in times of transition take up a decisive role. Transformation leadership is a crucial element for organizations who are willing to anticipate fundamental transitions and changes before they can encourage willingness of the workers and departments to recognize and implement those changes effectively in order to have an adequate environment for positive or adaptive changes through processes (for example, inspiration, motivation, alignment, and setting direction through vision). The innovative method of leadership is marked by a leader's ability to newly or uniquely perceive, evaluate and act, foster, and develop an inventive culture of the organization and motivate subordinates to put fresh thoughts into being and create the right structures to implement such ideas. The leader should have the unique talent to pull people together, bring them together to accomplish a shared objective, and to feel satisfied by excellent success. The leader must have desirable individual qualities. In order to gain respect, the leader must be moral, reasonable, hard, equal, and demonstrate confidence and a sense of direction that comes from a positive view of the future. People tend to obtain guidance from those who admire them and have a good sense of direction. A leader should have honesty-a quality that makes people trust in him/her. In all interpersonal relationships, trust is essential. The perception, particularly of the facts, is that integrity respects ideals or principles beyond it. The main principles are truth and trust as well as calm. He/she must display excitement and warmth in order to draw people. Leaders that display resilience, tenacity, ambition, and synergistic abilities in teamwork can achieve the same values in their communities. Leaders need to be authentic, willing to establish ties and mutual confidence by active listening with no prior assessment, open communication of view, acceptance of advice and critique, and foster peaceful and psychological safety. A company leader must succeed internally as well as in the corporate world, balance his/her ability with that of a creative team and provide tangible and authentic support for the goals that concentrate on the organization's operation. He/she should express his/her experience in courageous engagement with others to support the job success of his/her organization by using agile, multi-stage work with specific responsibilities.

The current research responded to a request for research on "the mediating mechanism in the transformational leadership process" (Ariyabuddhiphongs and Kahn 2017; Judge et al. 2006) as its mediation impacts clarify the circumstances under which transformational leadership is connected with results. The purpose of the research was intended to add to the theory of transformational leadership, which explains that the leadership style of transformation could adversely affect the turnover intention to invest by employee performance mediation. It was also predicted that the outcomes would be helpful for the perception of hospital employees, which shows that the transformative leadership style utilized by immediate managers would generate employee performance between their subordinates which would reduce the intention to sell subordinates. This research examined the interpretation of the transformative style and influence of the leadership style on the expectation of the workers to turn over and the mediatory effect of their success on the connection between transformative leadership and the intention to turn over. The research goals were the following:

1. Assessing the perception of employees of their supervisors' transformational leadership style and their turnover intention as well as performance. 2. Examining the supervisors' transformational leadership style impact on the turnover intention of employees. 3. Examining the mediating role of employee' performance on relationship between transformational leadership and turnover intention 


\section{Research Background and Hypothesis Development}

\subsection{Transformational Leadership}

Burns (1978) published his seminal work introducing the transformational leadership concept, and research into transformational leadership has grown to be a prevalent theory of organization (Judge and Bono 2000; Bass and Riggio 2006). As per Burns (1978, p. 4), “a transforming leader looks for potential motives in followers, seeks to satisfy higher needs, and engages the full person of the follower". Later, Bass and his colleagues built on Bass (1985), who suggested that transformation leadership consisted of intellectual stimulation, individualized consideration, idealized influence, and inspirational motivation. Transformative leadership was described as an action set that empowers followers to improve performance and translates followers' values, beliefs, and attitudes above and beyond demands and that are not merely enforcement (Bass 1985; Yukl 1999). Transformational leadership means that leaders are capable of allowing individuals within groups to collectively transcend their self-interests for the good of the group's as well as converting followers into disciples and motivating them to develop themselves to higher need levels through a number of transformational leadership subdimensions, involving charisma (later renamed idealized influence), intellectual stimulation, individualized consideration, and inspirational motivation (Avolio and Bass 1995). Transformation leaders produce a conceptual vision, communicate through enclosing as well as applying the metaphor, modeling the vision through "walking the talk", and consistently playing, along with form commitment for the vision (Avolio 1999; McShane et al. 2000). Transformational leaders encourage followers to achieve extraordinary outcomes by giving understanding as well as meaning. They support the goals and objectives of individual followers and the larger organization (Bass and Riggio 2006) and provides the followers with mentoring and support as well as coaching.

As per Bass (1985), four important dimensions (inspirational motivation, intellectual stimulation, charisma, individualized consideration) of transformational leadership are presented here, which are used for accomplishing this transformation of organizations and peers, as well as subordinates. Later, the fifth dimension was added and he changed charisma to idealized influence (Avolio and Bass 1995).

After 2 years, Bass and Avolio (1997) developed different scales for optimal influence as well as the idealized attribution of influence (attributed charisma). Idealized influence refers to the modeling of exemplary behaviors that are aligned with organizational goals. It indicates that a leader will go beyond their individual self-interest for the greater good of the group and make personal sacrifices for others' benefit. (Avolio and Bass 1995). The idealized influence dimension, as well as attributed charisma dimension, previously known as charisma (Bass 1985), is a central element in the process of transformation management and is considered a central element in transformation leadership (Yukl 1989; Bass 1985, 1990). It includes gaining others' confidence, respect, and trust by taking a stand on difficult problems, emphasizing the significance of values, commitment, purpose, and showing conviction, as well as signifying the decisions' ethical consequences. An element of inspirational motivation is connected to communicating a vision with confidence and fluency in a significant way, energizing others and increasing their enthusiasm as well as optimism for future tasks. While the vision is conceptually distinct from charisma, research has shown that inspirational motivation has a strong relationship with idealized power (Bass 1998). Individual consideration is the same as the consideration dimension from the Ohio State-Michigan studies (Yukl 1999) and includes attending to and supporting the individual followers' needs. Transformational leaders are the people who deal with others as individuals and understand that every person has dissimilar abilities and needs, and requires personal attention and to feel valued. Transformational leaders realize this by coaching, advising, teaching, developing, identifying, and valuing contributions of every individual, and listening attentively (Kark and Shamir 2002; Avolio et al. 2004; Bass and Avolio 1994; Avolio and Bass 1995). Intellectual stimulation includes stimulating follower creativity by challenging the status quo as well as questioning assumptions. As 
Bass (1985) noted, “By the transformational leader's intellectual stimulation, we mean the arousal and change in followers of problem awareness and problem solving, of thought and imagination, and of beliefs and values" (p. 99). Transformation leaders recognize that the only real ways to achieve a sustainable competitive advantage are innovation, creating knowledge, and continual development. They consistently question old assumptions as well as ways of doing things, encourage creativity, emphasize the use of knowledge, and inspire new viewpoints and ways of working in others. Transformational leaders promote the expression of new things and arguments from their subordinates (Bass and Avolio 1994). Intellectual stimulus is often perceived as a leader who thinks about logic, rationality, intelligence, and careful problem solving in organizations (Dionne et al. 2014). While widely utilized, in leadership studies, the conceptualization of TL in different dimensions is questionable. The four-dimensional form was not always observed, as per Den Den Hartog et al. (1997). No single dimensions have been specifically established (Mesu et al. 2015). The distinction between inspirational motivation and idealized influence is less obvious from a theoretical viewpoint, because charismatic leaders often have a tendency to encourage people with their views (Rowold and Heinitz 2007; Mesu et al. 2015). The distinction between individualization and intellectual stimulation can be complicated when both mention the development of employees (Mesu et al. 2015). Yukl (2006) proposed that there were conflicting findings for various TL components. Even though factor analyses endorse their characteristics, Fu et al. (2010) show that the measurements of their products are so interrelated that their different effects are difficult to determine clearly. Other researchers conducted one-dimensional factor analysis in which all dimensions were loaded into one factor (Bass and Riggio 2006; Antonakis et al. 2003). Hence, several TL studies have utilized composite factors only instead of four dimensions (Yukl 2006; Yucel et al. 2014; Top et al. 2013; Mesu et al. 2015; Gyensare et al. 2016).

Previous researchers observed TL's positive affect on attitudes and actions of employees (for example: task performance, commitment, trust, and job satisfaction) (Sanda and Kuada 2013; Judge and Piccolo 2004; Avolio et al. 2004; Aryee et al. 2012) and negative effects on turnover intention (Gyensare et al. 2016; Dupré and Day 2007). A transformational leader should use an innovative and imaginative leadership style that encourages supporters to decide independently and improve their work (Munir and Nielsen 2009). In short, the style of leadership is essential to the behavior and attitudes of the employees.

\subsection{Transformational Leadership Predicting Employee Performance and Turnover Intention}

Performance is the action to accomplish a goal (Armstrong and Taylor 2014). Performance is the analytical procedure with the intention of ensuring that all organizational processes are in order to maximize employees', teams', and the organization's productivity. Certain factors are essential for determining the performance of an individual in an organization. The performance of the variable is influenced by the job, including role stress as well as differences between working and non-working (Babin and Boles 1998).

There are certain factors, such as interpersonal relationship, cost effectiveness, punctuality, quantity, and quality, for assessing performance (Bernardin and Russell 2006). Mathis et al. (2015) said that the performance of the employees has certain elements, including loyalty, cooperation, attendance, accuracy, quality, and quantity. Transformation leadership is the most efficient form of leadership that encourages employees to take on constructive roles and extra roles (MacKenzie et al. 2001).

Transformational leaders motivate followers to increase their own interests; set high performance standards; provide feedback; pay attention to the needs of followers; and help followers to become more innovative as well as creative (Yukl 1999; Bass 1985). They also "motivate followers to achieve performance beyond expectations by transforming followers' attitudes, beliefs, and values" (Rafferty and Griffin 2004; Ariyabuddhiphongs and Kahn 2017). This will increase employee performance through transformance executives. Several meta-analyses have shown these beneficial effects (Lowe et al. 1996; Judge and Piccolo 2004; Fuller et al. 1996). Judge and Piccolo (2004) meta-analysis, for example, identified a positive 
correlation between organizational performance and transformational leadership. A study (Asbari et al. 2020; Purwanto et al. 2019) demonstrated that transformational leadership has a significant correlation with organizational performance, with or without any mediation. Based on the outcomes and the conclusions of the above research, the following hypotheses were made:

Hypothesis 1 (H1). Transformational leadership would predict turnover intention negatively.

Hypothesis 2 (H2). Transformational leadership would predict employee performance positively.

\subsection{Employee Performance Predicting Turnover Intention}

Across multiple fields of studies, various researchers have sought to establish a set of criteria which could assist in the prediction of employee turnover in an organization (Salamin and Hom 2005). Employee turnover, a phenomenon that has traditionally been viewed as a negative incident for organizations due to the costs that are associated with it, is now being viewed in a different light (Dalton et al. 1982; Staw 1980). Although there have been many studies that have sought to establish a relationship between employee performance and employee turnover, the results of these studies have been inconsistent and inconclusive (Jackofsky 1984). Positive, negative, and curvilinear performance-turnover relationships have all been found in various studies (Jackofsky et al. 1986), however, what these outcomes highlight is that the nature and direction of this relationship is largely ambiguous (Iverson and Deery 2000). The lack of consistency in the results has been attributed to both methodological and conceptual factors (Birnbaum and Somers 1993). Several scholars have argued that only testing for a linear relationship fails to take into account the complexity of the performance-turnover relationship, which could lead to reporting bias (Schwab 1991; Williams and Livingstone 1994 as cited in Hochwarter et al. 2001). Moreover, new conceptual outlooks suggest not only a curvilinear connection between employee turnover and performance, but also a probable interaction between employee performance and job satisfaction (Birnbaum and Somers 1993).

The March and Simon (1958) employee turnover model is one that has been widely studied and is the basis for many other turnover models that have since been proposed. March and Simon (1958), the seminal theorists in the field of employee turnover, suggest that employee turnover is a function of two factors, movement ease and movement desirability. An example of how this model has been suggested to impact the employee performance-turnover relationship is highlighted in an argument put forward by Schwab (1991), who claims that high performers are more likely to be employable in the external market and, thus, according to the March and Simon (1958) model, should have a higher ease of movement. Based on this, it is suggested that better performers are more likely to leave an organization than their poorly performing counterparts, thus resulting in a positive relationship between the two constructs. In contrast, there is also evidence to suggest that the stress of a tough performance review may increase the desirability of movement for a poor performer. Poorly performing individuals may voluntarily choose to leave an organization to avoid a stressful situation in the workplace (Jackofsky 1984), thus supporting the theory that poor performers are more prone to leaving an organization than high performers.

Although the above relationships are in complete contrast to each other, evidence has been found in support of both these arguments. Furthermore, there exists a group of theorists who believe that there is a connection between employee turnover and performance. They believe that the relationship between the constructs is curvilinear in nature and, if drawn in a graph format, would make a U-shaped curve (Jackofsky 1984). 
Studies have shown that employee performance does indeed often have an impact on employee turnover. This first portion of this research paper aims to contribute to the literature relating to the employee performance-turnover relationship. More specifically, it has been found that limited research has been carried out on this relationship in the Turkey context. Therefore, the study further aims to contribute to the body of knowledge by investigating the employee performance-turnover relationship in the business environment in the Turkey context.

A negative connection between employee turnover as well as performance is indicative of an association whereby when the performance of an individual decreases, the likelihood of that individual leaving the organization increases (Jackofsky et al. 1986). Evidence in support of this relationship has been found in numerous studies and dates as far back as 1949 (Giese and Ruter 1949). In most cases, the explanation for this type of relationship is grounded in the desirability of movement factor which was proposed in the March and Simon (1958) model.

The performance appraisal process has been cited as a factor that prompts poorer performing individuals to leave an organization (Jackofsky 1984). It was suggested that poor performers often experience heightened levels of stress and anxiety with regard to the performance review process (Jackofsky 1984). A negative performance appraisal can be a taxing experience and, as such, increases the desirability for a poor performer to leave the organization. Moreover, stressful events in one's work and personal life may prompt an individual to search for more role-relevant employment opportunities (as cited in Keller 1984). This argument is extended further by Allen and Griffeth (1999), who suggest that substandard performance often results in an individual questioning the essential worth of a job, thus causing increased frustration and anxiety. Individuals are often aware that a negative performance review can result in a dismissal (Jackofsky 1984) and, as such, the increase in pressure may cause the individual to search for other available employment opportunities as a mechanism to evade a difficult situation at work (Keller 1984). Based on the previous research that has been done that supports these relationships, a negative performance-turnover relationship seems somehow logical (McEvoy and Cascio 1987). Based on the findings as well as conclusions of this research, the following hypothesis was made:

Hypothesis 3 (H3). Employee performance would negatively predict turnover intention.

2.4. Employee Performance Mediating the Relationship between Transformational Leadership and Turnover Intention

Employee performance is described as "the extent to which employees successfully perform their tasks". Traditionally, research has analyzed the performance of employees with variable criteria (Quińones et al. 1995; Bono and Judge 2003). Reviewing the connections among employee performance and transformational leadership and turnover intention showed a potential function of the performance of the employee as a mediator in the turnover intention-transformational leadership correlation.

In a meta-analysis of 25 years of study, transformation leadership has been connected to the performance of individual followers based on 113 primary studies, with a stronger relation to contextual performance than to task performance (Wang et al. 2011). The transformation leadership mechanisms relating to employee performance included the coaching and competitiveness of salespeople (Shannahan et al. 2013), relations with their supervisor (Walumbwa and Hartnell 2011), the fulfillment of skill and connectivity requirements (Kovjanic et al. 2013), and the emotions of followers (Chi and Liang 2013). Transformation leadership was suggested to favorably predict employee performance. Though an early meta-analysis showed a negative correlation between voluntary turnover and supervisory rating (Bycio et al. 1990), later studies found that the connections between employee turnover and performance are curvilinear (Salamin and Hom 2005) and Ushaped (Hochwarter et al. 2001). The overall relationship between employee turnover and performance was identical in different countries, however, the aspects of this relationship 
were different from country to country (Sturman et al. 2012; Ariyabuddhiphongs and Kahn 2017). The essence of the connection between employee turnover and performance can also take into account the exposure and compensation contingencies (Allen and Griffeth 2001) (Sturman and Trevor 2001). In addition, employee performance can influence turnover by assessing the desire to change the company or the expectation of turnover cognitively or affectively (Allen and Griffeth 1999). As performance supervisory reviews were more linked to the plan to withdraw (Zimmerman and Darnold 2009) and as self-rated performances and managerial ratings have been negatively connected to turnover intentions (Biron and Boon 2013), the performance of employees would negatively predict turnover intention:

Hypothesis 4 (H4). Employee performance would negatively mediate the relationship of transformational leadership with turnover intention.

\section{Method}

\subsection{Sample and Procedures}

Participants were Turkish healthcare professionals of private Turkish hospitals in Ankara and İstanbul, the two biggest cities of Turkey. Healthcare organizations have an important health and wellbeing effect on society, but they are facing a multitude of challenges that corporate leadership has to solve. The quality of patient treatment and hospital results will be increased by evaluating TLs for hospital management and the level and performance of the healthcare workers (Ribeiro et al. 2018b).

A survey was undertaken to gather results to achieve the purpose of the analysis while ensuring that the respondents' responses were anonymous and confidential. All employees were presented with a questionnaire outlining the intention of the report, giving a confidentiality guarantee and notifying them of their voluntary involvement. The original English survey was translated by a bilingual speaker into Turkish. Another bilingual speaker then backtranslated the Turkish questionnaire into English to confirm the equivalence of the surveys (Brislin 1980). To conduct this survey, the author also asked for input from five management scholars along with nine hospital CEOs. The questionnaire was reworked by eight MBA students to confirm the effectiveness of the measurements and pre-test the updated edition.

Regarding the data collection process, all employees as well as their e-mail addresses were listed by the human resources departments of the hospitals. Possible participants were sent an email requesting their inclusion in the analysis and requested that employees who participate in the survey attend a session with the author after their work. The author sent confirmation postcards to workers who did not return the surveys 45 days after administration of the survey. A total of 650 questionnaire copies were distributed, 498 were returned and 20 excluded due to the incompleteness of the questionnaire. Of the 478 sample respondents, $58.3 \%$ were female, $69.6 \%$ were aged $24-46$, and $72 \%$ were graduates.

A bootstrapping technique was used by carrying out few enhancements in data analysis (Efron 1982) and calculating "the statistic of interest in multiple re-samples of the data set, and by sampling $\mathrm{n}$ units with replacement from the original sample of $\mathrm{n}$ units" (Preacher et al. 2007, p. 190), especially when evaluating meditational impacts the same as the ones which were foreseen in this study's analysis model (Ribeiro et al. 2018a).

\subsection{Measures}

There were four sections of the survey instrument. In Section I, demographic variables, for example, tenure, position, and age, as well as gender, were included. The three other sections comprised the latent structures employee turnover intention, employee performance, and transformational leadership. 


\subsubsection{Transformational Leadership (Independent Variable)}

For measuring transformational leadership, the MLQ Form 5X was used (Avolio and Bass 1995). The MLQ involves calculating the four dimensions of inspirational motivation, idealized influence, individualized consideration, and intellectual stimulation. Based on earlier studies, on average, 20 elements was compounded into a transformational leadership scoring (for example; Aryee and Chu 2012; Walumbwa et al. 2008). The participants were then asked to show, on a five-point scale (ranging from 1 "not at all" to 5 "frequently, if not always"), the extent to which their immediate supervisors partake in any of these behaviors. Cronbach's $\alpha$ was 0.89 for the calculation of composite transformational leadership.

\subsubsection{Employee Performance (Mediator Variable)}

The analysis used four elements from Rego and e Cunha (2008) to calculate EP. Sample items comprised: "I am happy with the quality of my work output" and "My manager believes I am an efficient worker". For the four-item employee turnover measure, the value of Cronbach's $\alpha$ was 0.87 .

\subsubsection{Turnover Intentions (Dependent Variable)}

Bothma and Roodt (2013) used a six-item scale to calculate the turnover intention of employees. The respondents were asked to show the probability they would leave their jobs on a five-point Likert scale varying from 1 "strongly disagree" to 5 "strongly agree". For the six-item turnover intention measure, the Cronbach's $\alpha$ value was 0.84 .

\subsubsection{Control Variables}

Tenure, marital status, age, and gender were controlled for due to their potential effect on turnover intention of employees, as stated by many studies (e.g., Moynihan and Landuyt 2008; Lu et al. 2007; Kim and Stoner 2008; Chang et al. 2013). Gender was a dichotomous variable $(0=$ male, $1=$ female $)$. Age was a continuous measure. Marital status was a dichotomous variable $(0=$ married, $1=$ single $)$. Finally, tenure with the company was computed with the following classes: "less than one year", "one to two years", "two to four years", "four to ten years", and "more than ten years".

\subsection{Common Method Bias Assessment}

Although self-reporting interventions (i.e., questionnaires) provide considerable advantages for researchers, such as ease of dissemination and cost, they appear to increase the possibilities of a general variation in methods, which creates inflating associations within the interest building (Crampton and Wagner 1994). In order to minimize the risk of this methodological distortion, the report followed suggestions from Podsakoff et al. (2003). Following these recommendations, in order to control for the impact of common method variance, first, respondents were sure of their confidentiality and anonymity prior to completing the questionnaire. Secondly, traditional experimental methods were used for psychological separation. The psychological separation of the various structures was a cover rubric. Third, a Harman (1976) one-factor evaluation is carried out to ensure that our measures were not problematic with traditional process prejudice. The Harman (1976) test, that indicated that the results were resilient to a common system variation, shows that there was no single element that was responsible for most of the covariance between tests. There was no common methodological prejudice (Podsakoff et al. 2003).

\section{Findings}

The results were evaluated with SPSS v24, AMOS v22.0, and HAYES PROCESS v3.4. Linear regression, as well as exploratory factor analysis, was conducted in the SPSS program. In addition, for confirmatory factor analysis, the AMOS program was also used. Furthermore, HAYES PROCESS analysis was performed to assess the mutual connection between variables and the indirect and direct effects among them (Hayes 2017). 


\subsection{Normality Test}

To test whether the data showed a normal distribution, the $\mathrm{z}$ values obtained by dividing the skewness and kurtosis values for each variable into their standard error values were examined.

The normality tests were carried out at the outset after the data were collected from the questionnaires to determine whether the data had a normal distribution. Tabachnick and Fidell (2013) suggest, for social research, that the distribution is natural if skewness and kurtosis values are between -1.5 and +1.5 . In this case, the skewness and kurtosis values of all variables were found to be within these limits when examining the data set from the analysis. Consequently, the tests that require a normal distribution in this analysis could be used.

\subsection{Factor Analysis Findings Related to Scales}

In this research, the used scale factor structure was determined by confirmatory and exploratory factor analyses. Values of Kaiser-Meyer-Olkin (KMO) higher than 0.60 and Bartlett's sphericity tests with a sphericity value of $<0.05$ in explanatory factor analysis were considered. On the other hand, the study omitted products with a load factor of less than 0.40 (Kerse and Naktiyok 2020).

The factor load of two (2) elements was derived due to having values under 0.40 in the exploratory factor analysis of the transformational leadership scale. The rest of the elements were analyzed, and reference parameters were established $(\mathrm{KMO}=0.967$; Bartlett's test $=0.000$ ), resulting in one factor structure. The item factor charges ranged from 0.754 to 0.895 . After analyzing the exploratory factor, confirmatory factor analysis was carried out. To verify the obtained factor structure and to improve the fitting index values, confirmation factor analysis was carried out and it was found that the one-factor structure was confirmed. As a result, 18 elements were combined into one factor, and about $72.5 \%$ of the overall variation of the building was clarified. Table 1 shows the model fit index of the scale.

No variables were required to be extracted in the exploratory factor review for the staff output level, and four elements were grouped into a factor of 1 . The study produced a single factor structure and reference parameters $(\mathrm{KMO}=0.865$; Bartlett's test $=0.000)$ were given. The loading on items of the scale between 0.687 and 0.775 was observed. To verify the obtained factor structure, confirmatory factor analysis was performed. In addition, about $76.1 \%$ of the overall variation in the structure was clarified. Table 1 shows the obtained values for fit index.

Additionally, the scale elements were taken under a single factor and reference parameters were set out for the scale in exploratory factor analysis $(\mathrm{KMO}=0.961$, Bartlett's test $=0.000$, factor loads $=0.775-0.874$ ). No variables were extracted, six elements were grouped under 1 , and about $82.3 \%$ of the overall variation in the structure was clarified. Table 1 shows the obtained values for fit index.

Table 1. The fit index results.

\begin{tabular}{ccccccc}
\hline Indexes & $\begin{array}{c}\text { Reference } \\
\text { Value }\end{array}$ & $\begin{array}{c}\text { Transformational } \\
\text { Leadership }\end{array}$ & $\begin{array}{c}\text { Employee } \\
\text { Performance }\end{array}$ & $\begin{array}{c}\text { Turnover } \\
\text { Intention }\end{array}$ & $\begin{array}{c}\text { Research } \\
\text { Model }\end{array}$ & $\begin{array}{c}\text { Model without } \\
\text { Mediating Variable }\end{array}$ \\
\hline CMIN/DF & $0<\chi^{2} / \mathrm{sd} \leq 5$ & 1.668 & 1.858 & 1.756 & 1.487 & 1.582 \\
\hline RMR & $\leq 0.10$ & 0.005 & 0.034 & 0.014 & 0.029 & 0.018 \\
\hline CFI & $\geq 0.90$ & 0.935 & 0.928 & 0.962 & 0.938 & 0.938 \\
\hline IFI & $\geq 0.90$ & 0.935 & 0.928 & 0.962 & 0.941 & 0.947 \\
\hline NFI & $\geq 0.90$ & 0.948 & 0.925 & 0.964 & 0.957 & 0.942 \\
\hline TLI & $\geq 0.90$ & 0.927 & 0.916 & 0.953 & 0.052 & 0.056 \\
\hline RMSEA & $<0.05-0.08 \leq$ & 0.057 & 0.068 & 0.064 & 0.052 & \\
\hline
\end{tabular}




\subsection{Tests of the Hypotheses}

In this study, before testing hypotheses, correlation analysis was utilized to determine the strength and direction of correlation among the variables of transformational leadership, employee performance, and turnover intention. Control variables (for example, tenure, marital status, age, and gender) were included in this correlation analysis. Table 2 shows the obtained findings.

Table 2. Relations among variables.

\begin{tabular}{|c|c|c|c|c|c|c|c|}
\hline Variables & MeanSS & 1 & 2 & 3 & 4 & 5 & 6 \\
\hline 1-Gender & 1.2980 .468 & 1 & & & & & \\
\hline 2 -Age & 2.5691 .278 & $0.224 * *$ & 1 & & & & \\
\hline 3-Marital Status & 1.4840 .578 & $0.244^{* *}$ & $-0.547^{* *}$ & 1 & & & \\
\hline 4-Tenure & 2.8760 .896 & 0.048 & $0.365^{* *}$ & $-0.251^{* *}$ & 1 & & \\
\hline $\begin{array}{l}\text { 5-Transformational } \\
\text { Leadership }\end{array}$ & 3.8760 .985 & -0.03 & $-0.142^{* *}$ & $0.135 * *$ & -0.103 * & 1 & \\
\hline 6-Employee Performance & 3.3890 .845 & 0.075 & $0.168^{* *}$ & -0.084 & 0.098 & $0.492 * *$ & 1 \\
\hline 7-Turnover Intention & 3.2780 .678 & $0.098^{*}$ & $0.171^{* *}$ & -0.096 & $0.167^{* *}$ & $-0.568 * *$ & $-0.457^{* *}$ \\
\hline
\end{tabular}

** Correlation is significant at the 0.01 level (2-tailed). ${ }^{*}$ Correlation is significant at the 0.05 level (2-tailed).

When the correlation among these variables was examined, as shown in Table 2, a significant and positive connection between transformational leadership and employee performance $\left(\mathrm{r}=0.492^{* *}\right)$ and between transformational leadership and turnover intention $\left(r=-0.568^{* *}\right)$ was obtained. The results also show that employee performance is negatively correlated to turnover intention $\left(\mathrm{r}=-0.457^{* *}\right)$.

After evaluating the direction and strength of the relationship among variables, research hypotheses were tested. The AMOS program for developed hypothesis testing was used to model structural equality. Moreover, it was identified before the study of structural equality modeling that there was a multicollinearity problem among variables. In terms of determining this issue, the variance inflation factor (VIF) values and the tolerance index values (transformational leadership and employee performance) were analyzed. There is major multicollinearity, which must be fixed, when VIF is greater than 10 or tolerance is less than 0.1 . VIF values were shown to be lower than 10 and tolerance rates were greater than 0.10 . It was therefore found that the study could be carried out on structural equality modeling. Analyzing the modeling of structural equality, the goodness of fit index values were sufficient (see Table 1).

To validate the model, SPSS v24 analysis with PROCESS dialogue was performed (Hayes 2017), which showed 95\% confidence as well as 5000 bootstrap samples (Zhao et al. 2010).

Path c (Figure 1A) shows that transformational leadership significantly negatively predicts turnover intention $(p<0.001, \mathrm{SE}=0.01, \beta=-0.05)$. Hypothesis 1 was accepted. Path a (Figure 1B) shows that transformational leadership significantly positively predicts employee performance $(p<0.001, \mathrm{SE}=0.05, \beta=0.09)$. Hypothesis 2 was accepted. Path $b$ (Figure $1 \mathrm{~B}$ ) shows that transformational leadership significantly positively predicts employee performance $(p<0.002, \mathrm{SE}=0.08, \beta=-0.23)$. Hypothesis 3 was supported. As shown in Figure 1B, transformational leadership predicts performance of employees significantly (path a, $p<0.001, \mathrm{SE}=0.05, \beta=0.09$ ) and employee performance significantly predicts turnover intention (path $\mathrm{b}, p<0.002, \mathrm{SE}=0.08, \beta=-0.23$ ). The indirect transformational leadership effect on turnover intention through the mediation of employee performance (path $\mathrm{a} \times$ path $\mathrm{b}, \beta=0.09 \times-0.23=-0.02, p<0.001, \mathrm{SE}=0.01$ ) was significant. Hypothesis 4 was supported. 


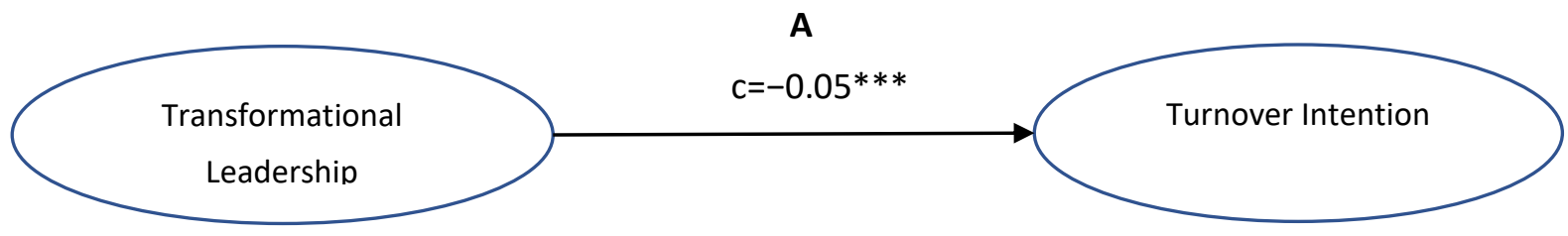

B

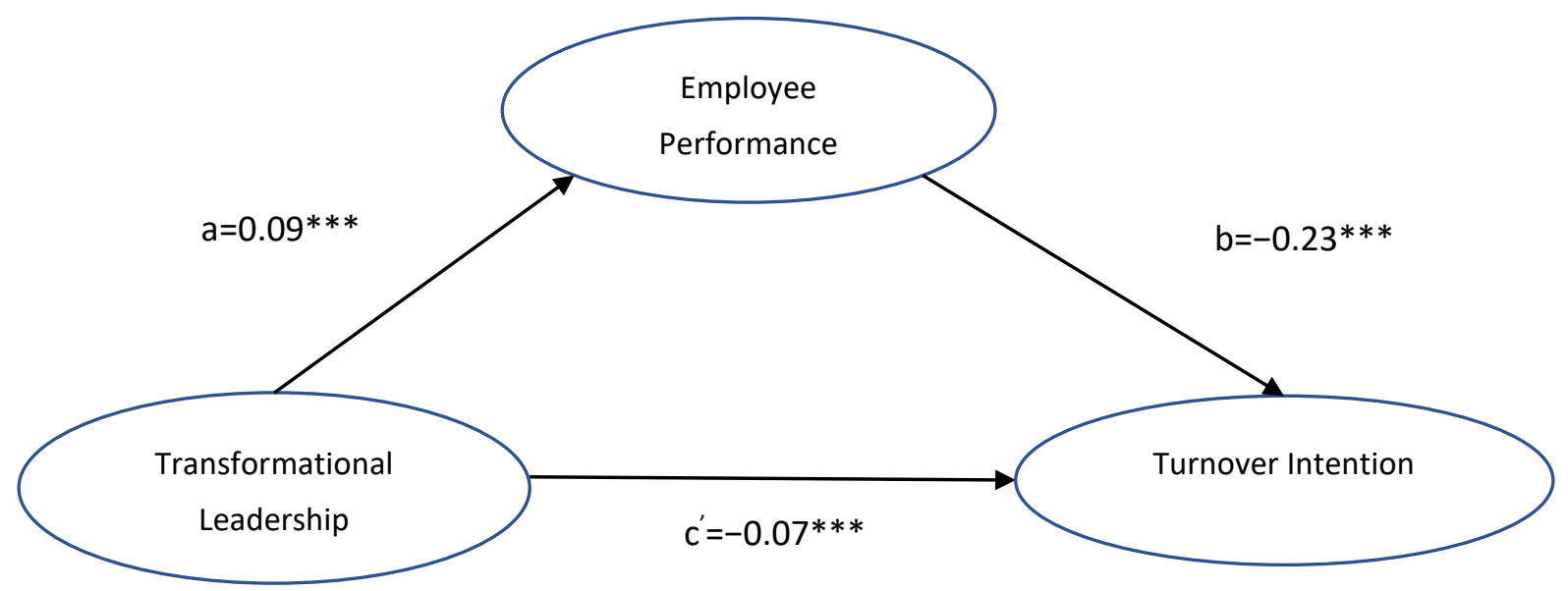

Figure 1. Hypothesized model tests. Tests of the hypothesized models. (A) Total effect (transformational leadership predicting turnover intention). (B) Indirect effect, with employee performance as mediator. Indirect effect $\beta=-0.02$, SE $=$ 0.01 . The predictor accounted for $48 \%$ of the variance in turnover intention. Standardized regression coefficients are display $* * * p<0.001$.

Therefore, the findings support the hypotheses, where transformational leadership predicts turnover intention negatively (Hypothesis 1), transformational leadership would positively predict employee performance (Hypothesis 2), employee performance would negatively predict turnover intention (Hypothesis 3 ), and employee performance (Hypothesis 4) negatively mediates the correlation of transformational leadership with turnover intention. Figure 1 and Table 3 show the regression analysis results.

Table 3. Bootstrap results to test significance of mediation effects (Direct and Indirect Effects).

\begin{tabular}{|c|c|c|c|}
\hline \multirow[b]{2}{*}{ Path/Effect } & \multicolumn{3}{|c|}{ Standardized } \\
\hline & $\beta$ & SE & $p$ \\
\hline c Total effect of Transformational Leadership on Turnover Intention & -0.05 & 0.01 & $<0.001$ \\
\hline a Transformational Leadership $\longrightarrow$ Employee Performance & 0.09 & 0.05 & $<0.001$ \\
\hline b Employee Performance $\longrightarrow$ Turnover Intention & -0.23 & 0.08 & $<0.001$ \\
\hline $\begin{array}{l}\text { c'Transformational Leadership } \longrightarrow \text { Turnover Intention } \\
\text { Indirect Effect }\end{array}$ & -0.07 & 0.01 & $<0.001$ \\
\hline $\mathrm{TL} \longrightarrow \mathrm{EP} \longrightarrow \mathrm{TI}$ & -0.02 & 0.03 & $<0.001$ \\
\hline
\end{tabular}

Notes: Bias corrected confidence intervals: transformational leadership employee performance turnover intention $=-0.05$ to -0.01 bootstrap re-samples $=5.000$. The $95 \%$ confidence interval for the standardized result was produced with bias corrected option in the bootstrap dialogue box in PROCESS procedures (Hayes 2017).

\section{Discussion and Conclusions}

\subsection{Discussion}

An organization's employees are among the most important commodities. Therefore, this becomes the central area of focus where leadership should lead in ways that increase employee engagement to effectively and efficiently achieve corporate goals, such as image, development, productivity, and profitability. This finding of the study shows a tendency to change the efficiency of employees and to achieve turnover among respondents. Hospital 
leaders must provide their subordinates with an atmosphere in which they can thrive socially and professionally. As per the finding of the study, it is recommended that hospital management pay more attention to better transformational leadership practices, therefore having a significant effect on employees' performance, or, if this is impossible, hospital management should consider new leadership practices, which are more appropriate for the conditions of employees in hospital that has more economically active employees with long years of service, i.e., more than 5 years. Next, management needs to maintain the habit of providing briefing as well as the motivation of the transformational leaders in the hospital, so they are able to keep up with the changes in the employees, especially in this COVID-19 pandemic situation. Employee turnover, although it has received much attention over the years, is still a topic which is relevant in organizations today. Understanding how employee performance impacts employee turnover not only adds to the body of knowledge relating to employee performance and employee turnover, but also highlights to leaders the risk they face in retaining their top performers. This is particularly pertinent in the current environment where organizations are competing for high-performing resources. Leaders are taught about both the legal and company processes that need to be followed in the event that they wanted to dismiss or discipline an individual for poor work performance. Furthermore, they are taught how to deal with high performers in terms of managing their expectations and offering them various challenges and growth opportunities that would assist in retaining the individual. This strong focus on performance within an organization may serve as a retention factor for high performers as their managers are subsequently in a better position to manage their careers. On the other hand, poor performers can now deal with leaders that are better equipped to deal with their poor performance.

Previous research called for more studies on transformational leadership in the hospitality sector (Hinkin and Tracey 1994) and transformation leadership showed direct impacts on the satisfaction of subordinates with their leader and indirect effects on transparency, role clarity, and mission clarity (Tracey and Hinkin 1996; Ariyabuddhiphongs and Kahn 2017). However, in the hospitality sector, research has primarily focused on employees. Transformational leadership will, for example, provide confidence, organizational loyalty, organizational citizenship (Yücel et al. 2020; Dai et al. 2013; Gill et al. 2010), authorization desire (Gill et al. 2010), and wellbeing among hotel employees (Kara et al. 2013; Ariyabuddhiphongs and Kahn 2017).

The correlation between turnover intention and transformation management has been studied less. Transformational leadership, for example, moderates the correlation between turnover and emotional exhaustion (Green et al. 2013) and decreases the fit between leadership styles and followers' self-regulation preferences (Hamstra et al. 2011). However, turnover intention was more indicative of turnover than total employee satisfaction, organizational commitment, and job satisfaction (Steel and Ovalle 1984). This research introduces attrition to the spectrum of transformational leadership results and broadens the perception of transformational leadership role.

Turkish hospital managers' transformative leadership seems to have an effect on employer building and increased efficiency, which in turn decreases the intention of subordinates to turn over. Transformational leadership partnership analysis has shown the beneficial effect of transformative leadership in Western developed countries (Wang et al. 2011), while comparable research is scarce in emerging countries, including Turkey. This research supports the application of the idea of transformational leadership in developed countries. Transformational leadership perception in Turkish hospitals improved the employee performance in hospitals positively and negatively affected their intention to quit and persuaded them not to leave the organization.

The obtained results in Turkey may also be valid in other developing nations. Employee performance has been historically seen as a result variable. In the correlations between turnover intention and transformational leadership, this study looked at employee performance as a mediating variable. Operationally, other studies described job performance as organizational records or contextual performance indicators (Riketta 
2008; Ariyabuddhiphongs and Kahn 2017), and obtained negative (Giese and Ruter 1949; Jackofsky et al. 1986; Bycio et al. 1990), positive (March and Simon 1958; Mathieu and Baratta 1989), curvilinear (Salamin and Hom 2005), and U-shaped (Hochwarter et al. 2001; Ariyabuddhiphongs and Kahn 2017) correlations between employee turnover and performance. The research evaluated employment performance as the perception level of the employees' performance and expectations for the performance of their managers. The same criteria have been shown to predict self-rated success and management performance (Biron and Boon 2013). Indicators were thought to represent the employees' understanding of their work success, and findings found that they compared work performance to the transforming managing style of their supervisors to estimate their intended turnover.

\subsection{Conclusions}

This research examined the interaction between turnover intention and transformational leadership and attrition and employee performance mediation in the correlation between turnover intention and transformational leadership. The findings demonstrate that transformational leadership predicts the turnover intention negatively and that the performance of employees moderates the association between turnover intention and transformational leadership. An immediate transformational leadership style of managers appears to decrease turnover intention through employee performance. The current research work has practical implications for hospital organizations. Whereas the transformational leadership prediction of turnover intention has been documented in this literature review, the research also suggests that transformational leadership could be a precursor of employee performance.

Transformative leadership allows employees to understand that the organization's activities, support, care, and values contribute to connections with the participants of the organization and developing a high degree of affective commitment to the organization. This connection must be reciprocal, and the principle of social exchange will justify it (Leroy et al. 2012). Based on reciprocity standards, there are transformational leaders that promote goal achievement, self-actualization, teamwork, and social support and thereby lower employer turnover through motivation and high demands of their workers, their vision for the company, and their support. A transformational leadership training program in immediate managers will allow them to increase job performance as well as decrease turnover intention. The training content will start with transformational concepts and transactional leadership principles along with outcomes of the study. Then, the trainees will be provided with examples of both types of leadership, including behavior, ability, and characteristics. Finally, trainees will take part in roleplay activities to conduct transformational leadership behaviors. Such training programs are important because hospital administrators do not know about transition transformational leadership or treatment. Employees may still not accept the concept of transformational leadership. The program's goal will first be to reach hospital' managers with high turnover issues that can help avoid the outflow of their employees. All new managers are also expected to receive training on leadership styles so that they will be utilized in their jobs. Such a training program includes the turnover concept as well as turnover costs for businesses and organizations. Hospital managers can track the results of their management styles by comparing the turnover rates of their hospitals before and after their training programs. If the turnover rates show a reduction, the organization will be helped by a decrease in the costs related to recruiting, selecting, and training new employees.

\section{Theoretical Contributions}

The current study contributes to leadership theory because it suggests that TL, a positive style of leadership, and employees' attitude to the organization by decreasing turnover, would improve the employees' performance. This study addresses specific calls from Avolio et al. (2009) for further research to explore the process and conditions for TL with valuable work outcomes. This makes it obvious that further study into 
the processes by which TL affects perceptions and activities related to working, such as employee engagement and the intention to invest, is needed to further appreciate the functioning of TL. This research also contributes empirically to the literature by evaluating the mediation in the relationship between TL and turnover intention. This contribution is a reply to a call for analysis on the mediation in the TL method, as the mediation results clarify the circumstances under which TL is linked to good outcomes (Judge et al. 2006). This research contributes to transformation leadership and work success literature and calls for a greater understanding of how performance influences turnover and different leadership types (Antonakis et al. 2012; Zaccaro 2012; Atkin-Plunk and Armstrong 2013). The results of this study go beyond previous studies on leadership and has indicated a strong linear connection between transformational management and the aim to carry out executive turnover. The research has particularly shown that restructuring leadership indirectly affects employee attrition intentions. Our results extend earlier findings on the importance of employee performance for organizations at various analysis echelons (Meyer et al. 2002). Our findings provide empirical evidence that the influence of employee understanding of the leadership style of their direct supervisors differs depending on their success (Walumbwa et al. 2008; Walumbwa and Hartnell 2011). In addition, it is imperative to consider the environment in which the research was carried out. Turkey is a collectivist society (Hofstede 1980; Yücel 2011) and therefore the context of Turkey provides justification for extrapolating research on transition leadership to the leading research on individualist societies in a collectivist community (Hofstede 1980; Yücel 2011). Lastly, this research examines the aforementioned relationships in the context of hospital staff during the COVID-19 pandemic period, and therefore makes a very important contribution to the theoretical literature. This research was the first of its kind to empirically investigate the indirect impact of transformational management on turnover intention by employee performance in the private hospitals of the two biggest cities in Turkey. Thus, this research contributes to the transformational leadership literature in numerous contexts.

\section{Implications for Practice}

This research contributes significantly to practical development by giving guidance to leaders and organizations on creating an environment for workers of admiration, involvement, participation, respect, and loyalty, which in turn helps to improve their performance as well as decrease turnover intention. Thus, organizations should also pursue transformational leadership and focus on leadership practices that will make it attractive to retain employees in the organization. The outcomes of the research have practical implications for organizations and, further, they give evidence of the useful effects of giving support to employees. Practitioners who want to significantly improve attitudes as well as behavior can achieve this by the favorable treatment and working conditions of the employees. Results from our research have realistic consequences for private organizations. As transformational leadership practice, including intellectual stimulation, individualized consideration, idealized influence, and inspirational motivation, raises the likelihood of reaching the company's objectives as well as goals, and limits employee turnover (Gyensare 2013; Gyensare et al. 2016), the research proposes the coaching and training of leaders and for organizations to be more transformational to provide a useful return on investment of employee growth.

Dvir et al. (2002) argues, for example, that these coaching and training projects are associated with improved levels commitment, satisfaction, motivation, and performance of followers. Most importantly, our research shows the mediation process that connects styles of the transformational leaders with the intention of the employees to leave. Our research also emphasizes the potential significance of employee performance to reduce employee turnover. Therefore, the greater the transformational leadership perceived by employees in hospitals, the higher the employee performance level, but the lower their turnover intention, as shown by Kanter's theory (Kanter 1984). During the COVID-19 pandemic period, it has been observed that hospital employees work by showing behaviors 
beyond their roles. In this period, this study once again demonstrated the importance of transformational leadership practices in order to keep healthcare workers working by pushing their own physical limits without thinking about leaving their jobs and without decreasing their performance below a certain level. With this experience, companies must select, establish, and invest in TL-style leaders. Such leaders (1) communicate a compelling vision, (2) provide emotional appeals and symbols to raise awareness of mutual goals, (3) create team spirit in followers, (4) stimulate followers to adopt new perspectives of work, (5) facilitate the followers' efforts to become more creative and innovative by questioning assumptions, (6) offer a supportive environment, (7) listen to the followers' individual needs, (8) facilitate individual development by mentoring, teaching, coaching, and inspiring, (9) treat followers with respect, and (10) are a representative to help followers to accomplish their missions as well as grow through individual challenges (Yücel et al. 2020). With transformational leadership comprising charisma (later renamed idealized influence), individualized consideration, inspirational motivation, and intellectual stimulation, it may be possible for employees to stay engaged and not leave their jobs under the difficult conditions of COVID-19. Moreover, developing effective leadership styles (for example, TL) and enhancing employee attitudes (such as decreasing turnover intention), are significant strategies for promoting the performance of employees. The findings of this study may also be very advantageous to healthcare service management by showing that the TL style utilized by supervisors might reduce the intention to leave, leading to performance improvement among healthcare professionals.

\section{Limitations and Future Research}

There are a few drawbacks to this analysis. The first drawback of this analysis is that it used the transformative management aspect only. However, transactional leadership may also be used in reports. The second constraint is that instead of the organizational documents or contextual efficiency, the operational definition of employee performance was the value of four items. Employees are believed to have a clear understanding of how they worked and what sort of assessment they would get from their supervisors. Future tests will further validate the self-assessed work success of the sample.

The third limitation is the utilization of self-reporting scales because only staff are capable of providing a sense of leadership style. The significance of the variables utilized in this analysis is supported and the scales used in our study do not overlap. A reasonable effort against traditional method prejudice is assumed to have been made (Conway and Lance 2010). The fourth limitation is that this research analyzes the transformational leadership effect towards turnover intention both indirectly and directly through the employee performance variable. This is may be due to a few other variables (for example, organizational climate, management knowledge, competency, motivation, etc.) that affect the performance of employees. The author also suggests analyzing, exploring, and discovering more in future studies. Furthermore, this particular research was carried out in hospitals and cannot be extended to other industries. The sample population used in this study consisted of Turkish healthcare professionals across the cities of Ankara and İstanbul in Turkey. Due to the limited diversity in the sample, the findings of this research work cannot necessarily be generalized to other types of workers or to other regions within Turkey.

Further studies on this concept in other sectors should also be proposed, and it can be applied to other countries, regions, or comparisons among large, medium, and small organizations. The survey method of collecting data has a set of drawbacks. One common problem with using surveys to collect data is that of missing data (Little 1988). Whilst there are statistical techniques which are commonly used to deal with missing data, these techniques do not always result in complete accuracy. Additionally, one mediating variable was used in the analysis, although others are possible. For example, TL may establish dedication to working and the organization which in turn improves the performance of its employees. Variables like mediators may be used in future experiments. Finally, there were no moderating factors. For example, future investigations might test to what extent 
the relationships between TL and the dependent variables are moderated by personal characteristics. In addition, future research could investigate these effects in a range of task studies or experimental studies. The impacts on subordinate results, which are moderated by other factors, should be explored through various scenarios.

Funding: This research received no external funding.

Institutional Review Board Statement: Not applicable.

Informed Consent Statement: Informed consent was obtained from all subjects involved in the study.

Data Availability Statement: Not applicable.

Conflicts of Interest: The author declares no conflict of interest.

\section{References}

Allen, D. G., and R. W. Griffeth. 1999. Job performance and turnover: A review and integrative multi-route model. Human Resource Management Review 9: 525-48. [CrossRef]

Allen, D. G., and R. W. Griffeth. 2001. Test of a mediated performance-turnover relationship highlighting the moderating roles of visibility and reward contingency. Journal of Applied Psychology 86: 1014. [CrossRef]

Antonakis, J., B. J. Avolio, and N. Sivasubramaniam. 2003. Context and leadership: An examination of the nine-factor full-range leadership theory using the Multifactor Leadership Questionnaire. The Leadership Quarterly 14: 261-95. [CrossRef]

Antonakis, J., D. V. Day, and B. Schyns. 2012. Leadership and individual differences: At the cusp of a renaissance. The Leadership Quarterly 23: 643-50. [CrossRef]

Ariyabuddhiphongs, V., and S. I. Kahn. 2017. Transformational leadership and turnover intention: The mediating effects of trust and job performance on café employees in Thailand. Journal of Human Resources in Hospitality \& Tourism 16: 215-33.

Armstrong, M., and S. Taylor. 2014. Armstrong's Handbook of Human Resource Management Practice, 13th ed. London: Kogan Page.

Aryee, S., and C. W. Chu. 2012. Antecedents and outcomes of challenging job experiences: A social cognitive perspective. Human Performance 25: 215-34. [CrossRef]

Aryee, S., F. O. Walumbwa, Q. Zhou, and C. A. Hartnell. 2012. Transformational leadership, innovative behavior, and task performance: Test of mediation and moderation processes. Human Performance 25: 1-25. [CrossRef]

Asbari, M., A. Purwanto, and P. B. Santoso. 2020. Pengaruh Iklim Organisasi dan Kepemimpinan Transformasional Terhadap Produktivitas Kerja Inovatif Pada Industri Manufaktur di Pati Jawa Tengah. Jurnal Produktivitas: Jurnal Fakultas Ekonomi Universitas Muhammadiyah Pontianak 7. [CrossRef]

Atkin-Plunk, C. A., and G. S. Armstrong. 2013. Transformational leadership skills and correlates of prison warden job stress. Criminal Justice and Behavior 40: 551-68. [CrossRef]

Avolio, B. J. 1999. Full Leadership Development: Building the Vital Forces in Organizations. Thousand Oaks: Sage.

Avolio, B. J., and B. M. Bass. 1995. Individual consideration viewed at multiple levels of analysis: A multi-level framework for examining the diffusion of transformational leadership. The Leadership Quarterly 6: 199-218. [CrossRef]

Avolio, B. J., W. L. Gardner, F. O. Walumbwa, F. Luthans, and D. R. May. 2004. Unlocking the mask: A look at the process by which authentic leaders impact follower attitudes and behaviors. The Leadership Quarterly 15: 801-23. [CrossRef]

Avolio, B. J., F. O. Walumbwa, and T. J. Weber. 2009. Leadership: Current theories, research, and future directions. Annual Review of Psychology 60: 421-49. [CrossRef]

Babin, B. J., and J. S. Boles. 1998. Employee behavior in a service environment: A model and test of potential differences between men and women. Journal of Marketing 62: 77-91. [CrossRef]

Bass, B. M. 1985. Leadership and Performance beyond Expectations. New York: Free Press.

Bass, B. M. 1990. Bass and Stogdili s handbook of leadership. New York: Free Press.

Bass, B. M. 1998. Transformational Leadership: Industrial, Military, and Educational Impact. Mahwah: Lawrence Erlbaum Associates.

Bass, B. M., and B. J. Avolio. 1994. Introduction. In Improving Organizational Effectiveness through Transformational Leadership. Edited by B. M. Bass and B. J. Avolio. Thousand Oaks: Sage Publications.

Bass, B. M., and B. J. Avolio. 1997. Full Range Leadership Development: Manual for the Multifactor Leadership Questionnaire. Palo Alto: Mind Garden.

Bass, B. M., and R. E. Riggio. 2006. Transformational Leadership, 2nd ed. Mahwah: Lawrence Erlbaum Associates Publishers.

Bernardin, H. J., and J. E. Russell. 2006. Human Resource Management. New York: Tata McGraw-Hill, p. 736.

Birnbaum, D., and M. J. Somers. 1993. Fitting job performance into turnover model: An examination of the form of the job performanceturnover relationship and a path model. Journal of Management 19: 1-11. [CrossRef]

Biron, M., and C. Boon. 2013. Performance and turnover intentions: A social exchange perspective. Journal of Managerial Psychology 28: 511-31. [CrossRef] 
Bono, J. E., and T. A. Judge. 2003. Self-concordance at work: Toward understanding the motivational effects of transformational leaders. Academy of Management Journal 46: 554-71.

Bothma, C. F., and G. Roodt. 2013. The validation of the turnover intention scale. SA Journal of Human Resource Management 11: 1-12. [CrossRef]

Brislin, R. W. 1980. Translation and content analysis of oral and written material. In Handbook of Cross-Cultural Research. Edited by H. C. Triandis and J. W. Berry. Boston: Allyn \& Bacon, vol. 1, pp. 389-444.

Burns, J. M. 1978. Leadership. New York: Harper \& Row.

Bycio, P., R. D. Hackett, and K. M. Alvares. 1990. Job performance and turnover: A review and meta-analysis. Applied Psychology 39: 47-76. [CrossRef]

Chang, W. J. A., Y. S. Wang, and T. C. Huang. 2013. Work design-related antecedents of turnover intention: A multilevel approach. Human Resource Management 52: 1-26. [CrossRef]

Chi, S. C. S., and S. G. Liang. 2013. When do subordinates' emotion-regulation strategies matter? Abusive supervision, subordinates' emotional exhaustion, and work withdrawal. The Leadership Quarterly 24: 125-37. [CrossRef]

Conway, J. M., and C. E. Lance. 2010. What reviewers should expect from authors regarding common method bias in organizational research. Journal of Business and Psychology 25: 325-34. [CrossRef]

Crampton, S. M., and J. A. Wagner II. 1994. Percept-percept inflation in microorganizational research: An investigation of prevalence and effect. Journal of Applied Psychology 79: 67. [CrossRef]

Dai, Y. D., Y. Y. Dai, K. Y. Chen, and H. C. Wu. 2013. Transformational vs transactional leadership: Which is better? A study on employees of international tourist hotels in Taipei City. International Journal of Contemporary Hospitality Management 25: 760-78. [CrossRef]

Dalton, D. R., W. D. Todor, and D. M. Krackhardt. 1982. Turnover overstated: The functional taxonomy. Academy of Management Review 7: 117-23. [CrossRef]

Den Hartog, D. N., J. J. Van Muijen, and P. L. Koopman. 1997. Transactional versus transformational leadership: An analysis of the MLQ. Journal of Occupational and Organizational Psychology 70: 19-34. [CrossRef]

Dionne, S. D., A. Gupta, K. L. Sotak, K. A. Shirreffs, A. Serban, C. Hao, D. H. Kim, and F. J. Yammarino. 2014. A 25-year perspective on levels of analysis in leadership research. The Leadership Quarterly 25: 6-35. [CrossRef]

Dupré, K. E., and A. L. Day. 2007. The effects of supportive management and job quality on the turnover intentions and health of military personnel. Human Resource Management: Published in Cooperation with the School of Business Administration, The University of Michigan and in Alliance with the Society of Human Resources Management 46: 185-201. [CrossRef]

Dvir, T., D. Eden, B. J. Avolio, and B. Shamir. 2002. Impact of transformational leadership on follower development and performance: A field experiment. Academy of Management Journal 45: 735-44.

Efron, B. 1982. The Jackknife, the Bootstrap and Other Resampling Plans. Society for Industrial and Applied Mathematics. Monograph 38. Philadelphia: SIAM.

Fu, P. P., A. S. Tsui, J. Liu, and L. Li. 2010. Pursuit of whose happiness? Executive leaders' transformational behaviors and personal values. Administrative Science Quarterly 55: 222-54. [CrossRef]

Fuller, J. B., C. E. Patterson, K. Hester, and D. Y. Stringer. 1996. A quantitative review of research on charismatic leadership. Psychological Reports 78: 271-87. [CrossRef]

Giese, W. J., and H. W. Ruter. 1949. An objective analysis of morale. Journal of Applied Psychology 33: 421. [CrossRef] [PubMed]

Gill, A., S. Fitzgerald, S. Bhutani, H. Mand, and S. Sharma. 2010. The relationship between transformational leadership and employee desire for empowerment. International Journal of Contemporary Hospitality Management 22: 263-73. [CrossRef]

Green, A. E., E. A. Miller, and G. A. Aarons. 2013. Transformational leadership moderates the relationship between emotional exhaustion and turnover intention among community mental health providers. Community Mental Health Journal 49: 373-79. [CrossRef] [PubMed]

Gyensare, M. A. 2013. Employee Turnover Intention: Empirical Examination of Antecedent and Outcome Variables. Master's thesis, Department of Organization and Human Resource Management, University of Ghana, Legon, Ghana.

Gyensare, M. A., O. Anku-Tsede, M. A. Sanda, and C. A. Okpoti. 2016. Transformational leadership and employee turnover intention. World Journal of Entrepreneurship, Management and Sustainable Development 12: 243-66. [CrossRef]

Hamstra, M. R., N. W. Van Yperen, B. Wisse, and K. Sassenberg. 2011. Transformational-transactional leadership styles and followers' regulatory focus. Journal of Personnel Psychology. [CrossRef]

Harman, H. H. 1976. Modern Factor Analysis. Chicago: University of Chicago Press.

Hayes, A. F. 2017. Introduction to Mediation, Moderation, and Conditional Process Analysis: A Regression-Based Approach. New York: Guilford Publications.

Hinkin, T. R., and J. B. Tracey. 1994. Transformational leadership in the hospitality industry. Hospitality Research Journal 18: 49-63. [CrossRef]

Hochwarter, W. A., G. R. Ferris, A. L. Canty, D. D. Frink, P. L. Perrewea, and H. M. Berkson. 2001. Reconsidering the Job-PerformanceTurnover Relationship: The Role of Gender in Form and Magnitude 1. Journal of Applied Social Psychology 31: 2357-77. [CrossRef] 
Hofstede, G. 1980. Culture's Consequences. Beverly Hills: Sage Publication.

Iverson, R. D., and S. J. Deery. 2000. Job performance and voluntary turnover: An examination of linearity, curvilinearity, and the moderators of time, unemployment rate, and perceived ease of movement using event history analysis. In Academy of Management Proceedings. Briarcliff Manor: Academy of Management, August, vol. 2000, pp. A1-A6.

Jackofsky, E. F. 1984. Turnover and job performance: An integrated process model. Academy of Management Review 9: 74-83. [CrossRef]

Jackofsky, E. F., K. R. Ferris, and B. G. Breckenridge. 1986. Evidence for a curvilinear relationship between job performance and turnover. Journal of Management 12: 105-11. [CrossRef]

Judge, T. A., and J. E. Bono. 2000. Five-factor model of personality and transformational leadership. Journal of Applied Psychology 85: 751. [CrossRef]

Judge, T. A., and R. F. Piccolo. 2004. Transformational and transactional leadership: A meta-analytic test of their relative validity. Journal of Applied Psychology 89: 755. [CrossRef] [PubMed]

Judge, T. A., E. Fluegge Woolf, C. Hurst, and B. Livingston. 2006. Charismatic and transformational leadership: A review and an agenda for future research. Zeitschrift für Arbeits-und Organisationspsychologie AEO 50: 203-14.

Kanter, R. M. 1984. Change Masters. Newyork: Simon and Schuster.

Kara, D., M. Uysal, M. J. Sirgy, and G. Lee. 2013. The effects of leadership style on employee well-being in hospitality. International Journal of Hospitality Management 34: 9-18. [CrossRef]

Kark, R., and B. Shamir. 2002. The influence of transformational leadership on followers' relational versus collective self-concept. In Academy of Management Proceedings. Briarcliff Manor: Academy of Management, August, vol. 2002, pp. D1-D6.

Keller, R. T. 1984. The role of performance and absenteeism in the prediction of turnover. The Academy of Management Journal $27: 176-83$. [CrossRef]

Kerse, G., and A. Naktiyok. 2020. The effect of interactional justice on work engagement through conscientiousness for work. Journal of Economy Culture and Society 61. [CrossRef]

Kim, H., and M. Stoner. 2008. Burnout and turnover intention among social workers: Effects of role stress, job autonomy and social support. Administration in Social Work 32: 5-25. [CrossRef]

Kovjanic, S., S. C. Schuh, and K. Jonas. 2013. Transformational leadership and performance: An experimental investigation of the mediating effects of basic needs satisfaction and work engagement. Journal of Occupational and Organizational Psychology 86: 543-55. [CrossRef]

Leroy, H., M. E. Palanski, and T. Simons. 2012. Authentic leadership and behavioral integrity as drivers of follower commitment and performance. Journal of Business Ethics 107: 255-64. [CrossRef]

Little, R. J. 1988. A test of missing completely at random for multivariate data with missing values. Journal of the American Statistical Association 83: 1198-202. [CrossRef]

Lowe, K. B., K. G. Kroeck, and N. Sivasubramaniam. 1996. Effectiveness correlates of transformational and transactional leadership: A meta-analytic review of the MLQ literature. The Leadership Quarterly 7: 385-425. [CrossRef]

Lu, K. Y., L. C. Chang, and H. L. Wu. 2007. Relationships between professional commitment, job satisfaction, and work stress in public health nurses in Taiwan. Journal of Professional Nursing 23: 110-16. [CrossRef]

MacKenzie, S. B., P. M. Podsakoff, and G. A. Rich. 2001. Transformational and transactional leadership and salesperson performance. Journal of the Academy of Marketing Science 29: 115-34. [CrossRef]

March, J. G., and H. A. Simon. 1958. Organizations. New York: John Wiley \& Sons Inc.

Mathieu, J. E., and J. E. Baratta. 1989. Turnover type as a moderator of the performance-turnover relationship. Human Performance 2: 61-71. [CrossRef]

Mathis, R. L., J. H. Jackson, and S. R. Valentine. 2015. Human Resource Management: Essential Perspectives. Boston: Cengage Learning.

McEvoy, G. M., and W. F. Cascio. 1987. Do good or poor performers leave? A meta-analysis of the relationship between performance and turnover. Academy of Management Journal 30: 744-62.

McShane, S. L., M. A. Y. Von Glinow, and R. Jing. 2000. Organizational Behavior. No. 658/M113. Boston: Irwin/McGraw-Hill.

Mesu, J., K. Sanders, and M. van Riemsdijk. 2015. Transformational leadership and organizational commitment in manufacturing and service small to medium-sized enterprises. Personnel Review 44: 970-90. [CrossRef]

Meyer, J. P., D. J. Stanley, L. Herscovitch, and L. Topolnytsky. 2002. Affective, continuance, and normative commitment to the organization: A meta-analysis of antecedents, correlates, and consequences. Journal of Vocational Behavior 61: 20-52. [CrossRef]

Moynihan, D. P., and N. Landuyt. 2008. Explaining turnover intention in state government: Examining the roles of gender, life cycle, and loyalty. Review of Public Personnel Administration 28: 120-43. [CrossRef]

Munir, F., and K. Nielsen. 2009. Does self-efficacy mediate the relationship between transformational leadership behaviours and healthcare workers' sleep quality? A longitudinal study. Journal of Advanced Nursing 65: 1833-43. [CrossRef]

Podsakoff, P. M., S. B. MacKenzie, J.-Y. Lee, and N. P. Podsakoff. 2003. Common method biases in behavioral research: A critical review of the literature and recommended remedies. Journal of Applied Psychology 88: 879-903. [CrossRef] [PubMed]

Preacher, K. J., D. D. Rucker, and A. F. Hayes. 2007. Addressing moderated mediation hypotheses: Theory, methods, and prescriptions. Multivariate Behavioral Research 42: 185-227. [CrossRef]

Purwanto, A., L. M. Wijayanti, C. C. Hyun, and M. Asbari. 2019. The Effect of Tansformational, Transactional, Authentic and Authoritarian Leadership Style toward Lecture Performance of Private University in Tangerang. Dinasti International Journal of Digital Business Management 1: 29-42. [CrossRef] 
Quińones, M. A., J. K. Ford, and M. S. Teachout. 1995. The relationship between work experience and job performance: A conceptual and meta-analytic review. Personnel Psychology 48: 887-910. [CrossRef]

Rafferty, A. E., and M. A. Griffin. 2004. Dimensions of transformational leadership: Conceptual and empirical extensions. The Leadership Quarterly 15: 329-54. [CrossRef]

Rego, A., and M. P. e Cunha. 2008. Authentizotic climates and employee happiness: Pathways to individual performance? Journal of Business Research 61: 739-52. [CrossRef]

Ribeiro, N., D. Gomes, and S. Kurian. 2018a. Authentic leadership and performance: The mediating role of employees' affective commitment. Social Responsibility Journal 14: 213-25. [CrossRef]

Ribeiro, N., İ. Yücel, and D. Gomes. 2018b. How transformational leadership predicts employees' affective commitment and performance. International Journal of Productivity and Performance Management 67: 1901-17. [CrossRef]

Riketta, M. 2008. The causal relation between job attitudes and performance: A meta-analysis of panel studies. Journal of Applied Psychology 93: 472. [CrossRef]

Robbins, S. P. 2003. Organization Behavior. Saddle River: Prentice-Hall.

Rowold, J., and K. Heinitz. 2007. Transformational and charismatic leadership: Assessing the convergent, divergent and criterion validity of the MLQ and the CKS. The Leadership Quarterly 18: 121-33. [CrossRef]

Salamin, A., and P. W. Hom. 2005. In search of the elusive U-shaped performance-turnover relationship: Are high performing Swiss bankers more liable to quit? Journal of Applied Psychology 90: 1204. [CrossRef]

Sanda, A., and J. Kuada. 2013. Identification of effective leadership indicators in Ghanaian retail banks using AMOS based confirmatory factor analysis. In Recent Advances in Business Administration, Marketing and Economics. Venice: BAME.

Schwab, D. P. 1991. Contextual variables in employee performance-turnover relationships. Academy of Management Journal 34: 966-75.

Shannahan, K. L., A. J. Bush, and R. J. Shannahan. 2013. Are your salespeople coachable? How salesperson coachability, trait competitiveness, and transformational leadership enhance sales performance. Journal of the Academy of Marketing Science 41: 40-54. [CrossRef]

Staw, B. M. 1980. The consequences of turnover. Journal of Occupational Behaviour 1: 253-73.

Steel, R. P., and N. K. Ovalle. 1984. A review and meta-analysis of research on the relationship between behavioral intentions and employee turnover. Journal of Applied Psychology 69: 673. [CrossRef]

Sturman, M. C., and C. O. Trevor. 2001. The implications of linking the dynamic performance and turnover literatures. Journal of Applied Psychology 86: 684. [CrossRef] [PubMed]

Sturman, M. C., L. Shao, and J. H. Katz. 2012. The effect of culture on the curvilinear relationship between performance and turnover. Journal of Applied Psychology 97: 46. [CrossRef]

T.C. Sağlık Bakanlığı. 2020a. COVID-19-Yeni Koronavirüs Hastalığı Güncel Durum. Available online: https:/ / covid19bilgi.saglik.gov. $\mathrm{tr} / \mathrm{tr} /$ (accessed on 4 February 2021).

T.C. Sağlık Bakanlığı. 2020b. Türkiye'deki Güncel Durum. Available online: https://covid19.saglik.gov.tr/ (accessed on 12 April 2021).

Tabachnick, B. G., and L. S. Fidell. 2013. Using Multivariate Statistics, 6th ed. Boston: Pearson.

Top, M., M. Tarcan, S. Tekingündüz, and N. Hikmet. 2013. An analysis of relationships among transformational leadership, job satisfaction, organizational commitment and organizational trust in two Turkish hospitals. The International Journal of Health Planning and Management 28: e217-e241. [CrossRef] [PubMed]

Tracey, J. B., and T. R. Hinkin. 1996. How transformational leaders lead in the hospitality industry. International Journal of Hospitality Management 15: 165-76. [CrossRef]

Walumbwa, F. O., and C. A. Hartnell. 2011. Understanding transformational leadership-employee performance links: The role of relational identification and self-efficacy. Journal of Occupational and Organizational Psychology 84: 153-72. [CrossRef]

Walumbwa, F. O., B. J. Avolio, and W. Zhu. 2008. How transformational leadership weaves its influence on individual job performance: The role of identification and efficacy beliefs. Personnel Psychology 61: 793-825. [CrossRef]

Wang, G., I. S. Oh, S. H. Courtright, and A. E. Colbert. 2011. Transformational leadership and performance across criteria and levels: A meta-analytic review of 25 years of research. Group $\mathcal{E}$ Organization Management 36: 223-70.

World Health Organisation. 2020. Coronavirus Disease (COVID-19) Outbrake 2020. Available online: https://www.who.int/ emergencies/diseases/novelcoronavirus-2019 (accessed on 18 April 2021).

Williams, C. R., and L. P. Livingstone. 1994. Another look at the relationship between performance and voluntary turnover. Academy of Management Journal 37: 269-98.

Yücel, İ. 2011. Entrepreneurial orientation, executives' individualism and firm performance: The moderating role of executives individualism. In Proceedings of the Fifth International Conference on Management Science and Engineering Management. Macau: World Academic Union-World Academic Press, pp. 260-64.

Yucel, İ., A. McMillan, and O. C. Richard. 2014. Does CEO transformational leadership influence top executive normative commitment? Journal of Business Research 67: 1170-77. [CrossRef]

Yücel, İ, N. Ribeiro, and D. R. Gomes. 2020. Perceived organizational support and employees' performance: The mediating role of affective commitment. International Journal of Management and Enterprise Development 19: 187-202. [CrossRef]

Yukl, G. 1989. Managerial leadership: A review of theory and research. Journal of Management 15: 251-89. [CrossRef]

Yukl, G. 1999. An evaluation of conceptual weaknesses in transformational and charismatic leadership theories. The Leadership Quarterly 10: 285-305. [CrossRef] 
Yukl, G. 2006. Leadership in Organizations, 6th ed. Upper Saddle River: Prentice Hall.

Zaccaro, S. J. 2012. Individual differences and leadership: Contributions to a third tipping point. The Leadership Quarterly 23: 718-28. [CrossRef]

Zhao, X., J. G. Lynch Jr., and Q. Chen. 2010. Reconsidering Baron and Kenny: Myths and truths about mediation analysis. Journal of Consumer Research 37: 197-206. [CrossRef]

Zimmerman, R. D., and T. C. Darnold. 2009. The impact of job performance on employee turnover intentions and the voluntary turnover process: A meta-analysis and path model. Personnel Review 38: 142-58. [CrossRef] 